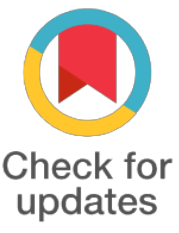

${ }^{*}$ For correspondence:

melindaremelia@gmail.com

Competing interests: The authors declare that no competing interests exist.

Received: 2017-04-29

Accepted: 2017-06-05

Published: 2017-09-05

Copyright The Author(s) 2017. This article is published with open access by BioMedPress (BMP).

This article is distributed under the terms of the Creative Commons Attribution License (CC-BY 4.0) which permits any use, distribution, and reproduction in any medium, provided the original author(s) and the source are credited.

\section{Optimized method for isolation of regenerative stromal cells from human lipoaspirates}

\author{
Melinda Remelia, Melinda Remelia, Imam Rosadi, lis Rosliana, Siti Sobariah, \\ Karina
}

Hayandra Clinic Jalan Kramat Vi No.11, Salemba, Jakarta, DKI Jakarta 13430, Indonesia

\section{Abstract}

Background: One of the problems encountered in the stromal vascular fraction (SVF) cells therapy as a regenerative medicine is finding an effective and efficient method of adipose tissue processing. In this study, we try to improve the whole adipose processing method so it is not only generates high yield SVF, but also could saving cost and time. Methods: Each $30 \mathrm{ml}$ of subcutaneous adipose from twelve patients is separated into three groups treatments as follows: Group A treated with trypsin-EDTA, Group B with recombinant enzyme, and Group $C$ with a commercial kit. The number and viability of SVF cells in each methods is determined. The product of SVF is seeded in culture condition. The attached cells analysed with CFU-F testing, FACS assay, and differentiation capability assay are performed to confirm the stem cells properties. Results: The average of SVF cells number per $10 \mathrm{ml}$ of adipose in Group A: $1.7 \times 106$ cells (96.58\%), Group B: $5.1 \times 107$ cells (97.85\%), and Group C: $1.9 \times 107$ cells (96.86\%). The result of modified of method B produces up to $1.1 \times 109$ per $10 \mathrm{ml}$ of adipose. Findings or Conclusion: We improved the whole adipose processing method from method previously described. We use non-animal derived recombinant enzyme, more cost and time saving proven compare to collagenase, with the higher yields than that obtained from collagenase, trypsin, or its both combination method.

\section{Keywords}

stromal vascular fraction, lipoaspirate, adipose derived stem cells, regenerative medicine

Funding

Hayandra Foundation

\section{References}

